Вісник Національного університету “Львівська політехніка”. Серія "Проблеми економіки та управління"

T. 4, № 1, 2020

UDK 336.744

JEL Classification Code G11

I. Yu. Kondrat, N. B. Yaroshevych, M. V. Lyvdar, R. I. Drala

Lviv Polytechnic National University,

Department of Finance

\title{
EVALUATING CRYPTO PORTFOLIO PERFORMANCE
}

http://doi.org//10.23939/semi2020.01.011

(C) Kondrat I. Yu., Yaroshevych N. B., Lyvdar M. V., Drala R. I., 2020

Cryptocurrency draws a lot of attention from both the academic community and investors, government regulators and the general public. It is not yet fully understood whether it is a type of digital financial asset or a new form of money. The legal status of cryptocurrency varies substantially across countries, and is uncertain in Ukraine.

The purpose of the article is to determine the characteristics of cryptocurrency and its legal status in Ukraine, to create well-formed cryptocurrency portfolios with different risk and returns, to evaluate their performance, to explore portfolio diversification opportunities through cryptocurrencies in new financial reality.

There are three features that distinguish cryptocurrency market: high risk due to volatility of returns, fundamental value is unclear, investors are non-institutional.

The following key characteristics of cryptocurrency are defined: decentralized and no central authority; anonymous; irreversible and immutable (can not be undone); limited supply and scarcity; the use of a peer-to-peer database; secure; trustless; global; fast.

Despite the awareness of state regulators about the opportunities and threats that could be expected from cryptocurrency, the approach may be different due to the country: the absolute prohibition (Nepal, Pakistan, Vietnam, etc.); the neutral status (most countries), cryptocurrency transaction registration and licensing required (Italy, Australia and Japan, etc.), permission to use a cryptocurrency as a mean of payment (Isle of Man, Mexico).

Central banks strongly emphasize the distinguish of cryptocurrencies, that are not supported by any official authority, from legal means of payment and financial assets, recognizing the dangers that cryptocurrency investors may face due to its speculative nature. Because cryptocurrencies can potentially be used for illicit activities, tax evasion, legislative acts need to be developed and implemented in Ukraine now. The draft law proposes to consider cryptocurrency as a virtual asset in the form of a token that is generated,accounted for and disposed of in a distributed registry and does not certify the proprietary and/or nonproprietary rights of the cryptocurrency owner. Therefore, cryptocurrency can be seen as an individual asset class suitable for portfolio investing.

To justify an investment in cryptocurrencies by non-institutional investors optimal portfolios were constructed using the Markowitz and Quasi-Sharpe models. The calculations showed that cryptocurrency portfolios performed on the basis of the Markowitz model allow to improve the investment returns, but are not sufficiently diversified. A large number of diversified portfolios with different returns and risk were obtained by Quasi-Sharpe model. They offer the highest expected return for a specific level of risk. 


\section{Yu. Kondrat, N. B. Yaroshevych, M. V. Lyvdar, R. I. Drala}

It has been empirically established that cryptocurrencies have weak brelationships with traditional asset classes. That is why portfolio diversification with cryptocurrencies can significantly improve the investment result.

Despite jaw-dropping returns, cryptocurrencies are rife with risk because of excessive volatility, no fundamental backing by a central bank or a government, low scalability, regulatory issues, limited use, activities of hackers and cybercriminals.

Keywords: cryptocurrency, investment portfolio, optimization models, portfolio performance, diversification.

\section{Problem statement}

Cryptocurrency attracts a lot of attention among academic community and investors, government regulators, public at large. However, it is not yet fully understood, either it is a type of digital financial asset, or a new money form. A legal status of cryptocurrency differs significantly in different states and it is unresolved in Ukraine. Along with this, cryptocurrency de facto exists, crypto operations volumes increase, resulting in the necessity to identify its essence, characteristics, scope of application, taxation, etc. In case of recognition the cryptocurrency as a financial asset, the question arises whether it is advisable and efficient to invest in it for non-institutional investors.

\section{Analysis of recent researches and publications}

While considering cryptocurrency within the framework of the neoclassical theory of finance, including the Markowitz portfolio theory, traditional asset pricing models, the efficient market hypothesis, scientists $[1,2]$ recognize it to be a speculative asset rather than a money substitute. Baur, Hong, and Lee [3] found that Bitcoin, which occupies the largest share of the cryptocurrency market, is mainly used as a speculative tool, and not as an alternative currency. The speculative nature of cryptocurrency would upset the balance in the financial market of Ukraine, the operations on which are aimed more at achieving high investment returns than ensuring GDP growth [4]. The results of empirical studies [3,5] find that cryptocurrency is uncorrelated with traditional asset classes such as stocks, bonds and commodities both in normal times and in periods of financial turmoil, which suggests their suitability for diversification of the investment portfolio with short horizons.

Representatives of behavioral finance have a different point of view on cryptocurrency [6,7], which associate two types of uncertainty with it: the complexity of the technology for unsophisticated traders, and the fundamental value is unclear. Of crucial importance for reducing uncertainty is obtaining relevant information, and its limited nature encourages investors to emulate others. Shiller [8] notes that there are market participants who can make irrational decisions contrary to the assumption of rationality. Errors affect prices and return of assets, creating market inefficiencies. Inefficiency (for example, under- or overreaction to information) is the reason for the change in market trends, and in some cases, this leads to the appearance of "financial bubbles", which happened with bitcoins at the end of 2017 [9].

\section{Setting objectives}

The purpose of the article is to determine the characteristic features of cryptocurrency and its legal status in Ukraine, to form optimal investment portfolios with cryptocurrencies with different levels of profitability, to evaluate their performance, to determine the prospects for diversifying an investor's portfolio using cryptocurrency in modern financial realities.

\section{Presentation of the main results}

The cryptocurrency market has three differences from the market of traditional financial instruments: high risk due to significant volatility of returns, uncertainty of the fundamental value, investors in cryptocurrency are non-institutional. 


\section{Evaluating crypto portfolio performance}

Cryptocurrency has the following characteristic features:

1) digital form (no coins or banknotes);

2) decentralization (there is no central computer or server, it is distributed over the network of a large number of computers);

3) peer-to-peer network (cryptocurrency is transferred from person to person on the Internet without any intermediaries, such as a bank or PayPal);

4) anonymity (there is no need to submit any personal information in order to own and use cryptocurrency);

5) the absence of trusted third parties means that users do not have to trust the system for it to work; the user constantly controls his money independently;

6) encryption (each user has special codes that make it impossible to use information by other users);

7) globality (there are no borders for cryptocurrency, it can be easily sent all over the world).

The advantages of cryptocurrency:

- when used as a medium of exchange, cryptocurrencies have the same anonymity as cash;

- unlike account-based payment systems, which require the participation of a financial intermediary to make a payment, cryptocurrencies use a payment system on the basis of value or token, which provides for the transfer of the object of payment such as commodities or fiat currency. Thus, there is a change in the way money is created in the reverse order - from credit money to commodity money. In the last century, money was primarily based on credit relations between banks and customers. Cryptocurrency, on the contrary, is no one's obligations and is similar in nature to commodity money;

- provide an opportunity to carry out operations at huge distances;

- the unit of account can be divided into smaller units, which is beneficial for micropayments in the digital economy;

- unlike bank transfers, clearing and settlements using cryptocurrencies are quickly carried out without an intermediary, acquiring special significance for cross-border payments; reduction in the cost of cross-border transfers;

- cryptocurrencies, as a rule, are not currencies, but rather financial assets and investments with a high degree of risk;

- since about 2 billion people in the world, many of whom are women, do not have bank accounts or live in states, where military operations continue (for example, Syria, Yemen, Libya, Afghanistan, Sudan and others), the use of cryptocurrency gives this people financial freedom;

- insignificant inflation risk, since the cryptocurrency offer is limited (as of January 13, 2018, miners mined 16.8 million bitcoins, which makes up $80 \%$ of the total volume (21 million) [10].

Cryptocurrency disadvantages:

- riskiness (they do not enjoy the same confidence among citizens as fiat currency, many cases of fraud, hacking, denial of work, use in illegal activities, etc. related to cryptocurrency are known);

- $\quad$ significant volatility (unlike fiat currencies, the value of which is determined by their legal tender status and the monetary policy of the Central Bank, the value of cryptocurrency depends on the expectation that other people will value and use them. In the second half of 2017, the price of bitcoin reached its historical maximum of $\$ 19$ thousand, in December 2018 it fell to $\$ 3.3$ thousand, but in spring of 2019 it more than doubled and reached almost $\$ 9$ thousand. In the first two weeks of 2020, bitcoin went up by $20 \%$ [11];

- the absence of three important functions performed in conditions of stable monetary regimes: protection against the risk of structural deflation, the ability to respond flexibly to temporary shocks in the demand for money in order to smooth out the economic cycle and perform as a lender of last resort;

- unlike fiat currencies, the cost of mining cryptocurrency is high because it requires a large amount of energy for a significant number of computers that solve cryptographic puzzles;

- decentralized issue means that cryptocurrency is not supported by any organization, therefore, its operation is associated exclusively with the users' trust;

- the anonymity of cryptocurrency means the possibility of its use for money-laundering, terrorist financing or other illegal actions; 


\section{Yu. Kondrat, N. B. Yaroshevych, M. V. Lyvdar, R. I. Drala}

- a hypothetical possibility of reducing the demand for money of the Central Bank and the creation of problems associated with the control of the money supply.

According to Christine Lagarde, a former IMF managing director [12], crypto assets is an example of the new technologies use to provide financial services, they have prospects, but they pose certain risks. So far, crypto assets do not threaten stability (all crypto assets together cost less than $1 \%$ of world GDP [13]), but require monitoring, supervision, regulation and control.

These issues are particularly relevant due to the fact that the financial market infrastructure is very vulnerable to cybercrime. Successful cyberattacks can trigger a chain reaction of defaults and have massive consequences. Therefore, state bodies should regulate the cryptocurrency turnover in order to prevent regulatory arbitrage and obtain unfair competitive advantages by individual entities: take measures to prevent money laundering and financing terrorism, strengthen consumer protection, and effectively tax cryptocurrencies. In addition, the central banks of states should develop measures that will increase the attractiveness of fiat currencies for administrating payments, evaluate the feasibility of issuing their own digital currency. However, then the problem of a massive outflow of deposits from banks in favor of digital money may arise.

Despite the state regulators' awareness about the opportunities and threats that can be expected from the functioning of cryptocurrencies, countries have taken different approaches: an absolute prohibition (Nepal, Pakistan, Vietnam, etc.); status of neutrality (most countries of the world), the need to register and licensing of operations with cryptocurrency (Italy, Australia and Japan, etc.), permission to use cryptocurrency as legal tender (Isle of Man, Mexico).

Central banks emphasize insistently the difference between cryptocurrency, which is not supported by any official body, from legal tender and financial assets, recognizing the danger that threatens cryptocurrency investors through its speculative nature. Considering the fact that cryptocurrencies can be used to finance illegal operations, tax evasion, etc., the development and implementation of regulations governing its functioning is now relevant. The legal status of cryptocurrency has not yet been determined in Ukraine. However, there have already been attempts to determine its essence, streamline the turnover and tax the income from crypto operations. In particular, the draft law "On the circulation of cryptocurrency in Ukraine" proposes to define cryptocurrency as a program code (a set of symbols, numbers and letters) that is an object of ownership, which can perform as a medium of exchange, information about which is entered and stored in the blockchain system as accounting units of the current blockchain system in the form of data (program code) [14]. The Law of Ukraine [15] introduces FATF and European Union Directives into Ukrainian legislation and contains regulations on the financial monitoring of crypto operations. It defines that a virtual asset is a digital expression of value that can be traded digitally or transferred and that can be used for payment or investment purposes. The Verkhovna Rada of Ukraine has registered a draft law "On Amending the Tax Code of Ukraine and other laws of Ukraine regarding the taxation of transactions with crypto assets" [16], which proposed to consider a crypto asset as a type of virtual asset in the form of a token that is created, recorded and disposed of in a distributed registry and does not certify the property and / or non-property rights of the crypto asset owner of. So, cryptocurrency will be considered as an investment asset.

Let us to create an investment portfolio of ten cryptocurrencies with the highest market capitalization. Their market capitalization indicators and prices are represented in Table 1 .

Table 1

Market capitalization and prices of leading cryptocurrencies as of Dec. 15, 2019

\begin{tabular}{|c|c|c|c|c|c|}
\hline Name & Market capitalization, $\$$ & Price, \$ & Name & Market capitalization, \$ & Price, $\$$ \\
\hline Bitcoin & 129481424648 & 7152,30 & Litecoin & 2784724201 & 43,76 \\
\hline Ethereum & 15589117504 & 143.11 & EOS & 2430995703 & 2.57 \\
\hline XRP & 9467680410 & 0.22 & $\begin{array}{c}\text { Binance } \\
\text { Coin }\end{array}$ & 2253796378 & 14.49 \\
\hline Tether & 4127007370 & 1.00 & Bitcoin SV & 1689052393 & 93.48 \\
\hline $\begin{array}{c}\text { Bitcoin } \\
\text { Cash }\end{array}$ & 3767572455 & 207.36 & Stellar & 1030780417 & 0.05 \\
\hline
\end{tabular}

Source: coinmarketcap.com. 


\section{Evaluating crypto portfolio performance}

The input data to the study is the daily value of their prices from 11/11/2018 to $12 / 15 / 2019$ (400 observations). Implementing the Markowitz model, an effective set of cryptocurrency portfolios has been developed (Fig. 1). The results slightly differ from those obtained previously [17].

Fig. 1 shows that there is an almost direct correlation between changes in profitability and risk for the totality of all possible portfolio options. There may be a number of reasons why the graph of the cryptocurrency portfolios resulting set differs from its classic look. Probably, the reason is the low profitability of its components for the analyzed period, as well as a small number of portfolios, which are possible to be formed under the restrictions defined. Some of the possible options for the structure of portfolios with different levels of return are presented in Table. 2.

Table 2

The structure of optimal portfolios obtained through the Markowitz model with different returns and risk

\begin{tabular}{|l|c|c|c|c|c|c|c|}
\hline Portfolio returns, \% & 0.05 & 0.10 & 0.15 & 0.20 & 0.25 & 0.30 & 0.35 \\
\hline Portfolio risk, \% & 1.08 & 1.94 & 2.87 & 3.81 & 4.75 & 6.25 & 8.63 \\
\hline Bitcoin SV weight, \% & 4.61 & 9.57 & 14.54 & 19.50 & 24.46 & 53.55 & 86.12 \\
\hline Tether weight, \% & 81.90 & 62.05 & 42.20 & 22.35 & 2.51 & 0.00 & 0.00 \\
\hline Binance Coin weight, \% & 13.49 & 28.38 & 43.26 & 58.15 & 73.04 & 46.45 & 13.88 \\
\hline
\end{tabular}

Source: authors' own study.

In accordance with the Markowitz model, the optimal portfolio can consist of three cryptocurrencies. Bitcoin SV and Binance Coin have been included in it due to relatively high rates of return, while Tether is characterized by a low risk. Depending on the requirements, the investor can choose the best option for the returns and risk, however, the results cast doubt on the feasibility of such an investment.

Let us form an effective set of portfolios according to the Quasi-Sharpe model (Fig. 2).

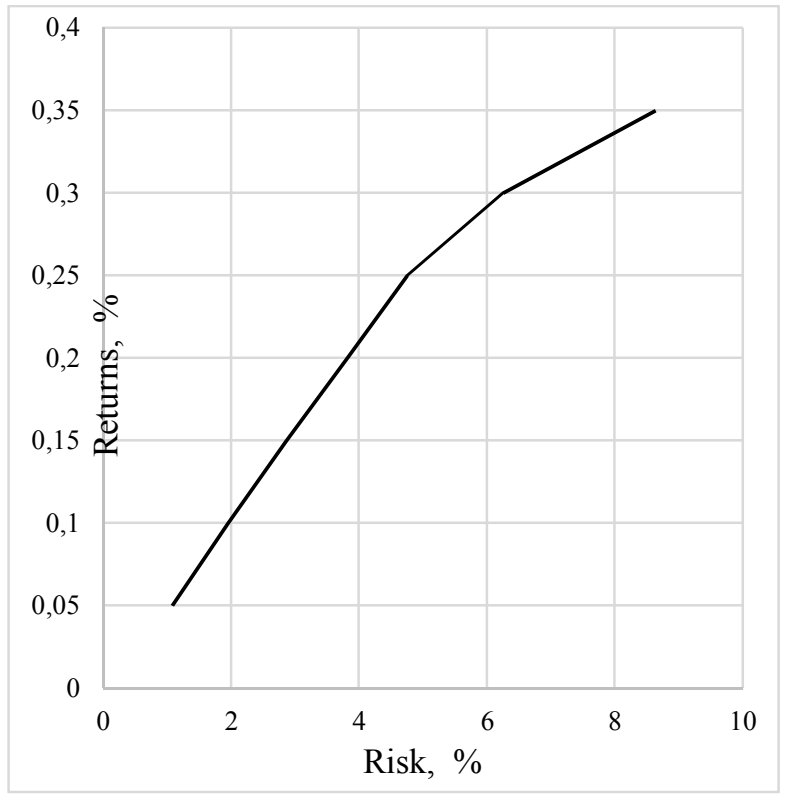

Fig. 1. Cryptocurrency efficient frontier obtained through the Markowitz model

Source: authors' own study.

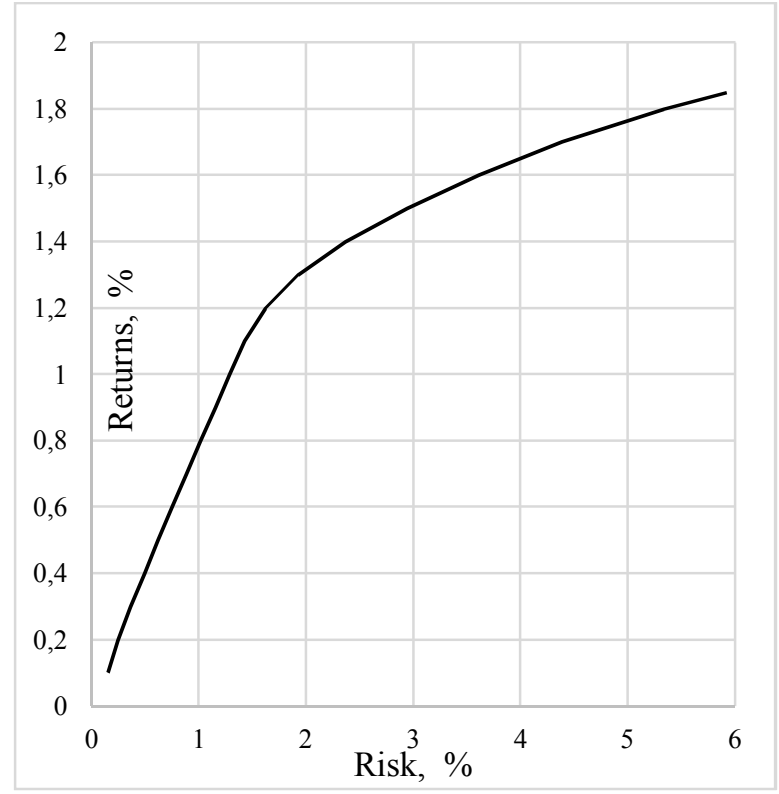

Fig. 2. Cryptocurrency efficient frontier obtained through the Quasi-Sharpe model 
The structure of optimal portfolios obtained through the Quasi-Sharpe model with different returns and risk

\begin{tabular}{|l|c|c|c|c|c|c|c|c|c|c|}
\hline $\begin{array}{l}\text { Portfolio } \\
\text { returns, \% }\end{array}$ & 0.10 & 0.30 & 0.50 & 0.70 & 0.90 & 1.00 & 1.10 & 1.30 & 1.50 & 1.70 \\
\hline $\begin{array}{l}\text { Portfolio } \\
\text { risk, \% }\end{array}$ & 0.15 & 0.36 & 0.62 & 0.88 & 1.15 & 1.28 & 1.42 & 1.92 & 2.94 & 4.38 \\
\hline Bitcoin, \% & 0.92 & 3.85 & 6.79 & 9.72 & 12.65 & 14.13 & 15.38 & 8.95 & 0.00 & 0.00 \\
\hline Ethereum, \% & 0.64 & 2.72 & 4.81 & 6.89 & 8.99 & 10.02 & 11.57 & 10.99 & 2.22 & 0.00 \\
\hline XRP, \% & 0.72 & 2.87 & 5.02 & 7.16 & 9.31 & 10.38 & 12.60 & 0.00 & 0.00 & 0.00 \\
\hline Bitcoin Cash, \% & 0.45 & 1.97 & 3.49 & 5.01 & 6.52 & 7.29 & 8.22 & 13.53 & 20.31 & 23.29 \\
\hline Bitcoin SV, \% & 0.52 & 2.37 & 4.22 & 6.07 & 7.92 & 8.84 & 9.89 & 21.82 & 42.94 & 70.44 \\
\hline Tether, \% & 94.15 & 75.16 & 56.17 & 37.19 & 18.20 & 8.71 & 0.03 & 0.00 & 0.00 & 0.00 \\
\hline Litecoin, \% & 0.62 & 2.70 & 4.78 & 6.85 & 8.4 & 9.97 & 11.06 & 15.22 & 16.68 & 6.28 \\
\hline EOS, \% & 0.53 & 2.28 & 4.04 & 5.80 & 7.56 & 8.43 & 9.08 & 11.60 & 9.81 & 0.00 \\
\hline $\begin{array}{l}\text { Binance } \\
\text { Coin, \% }\end{array}$ & 0.95 & 4.08 & 7.21 & 10.34 & 13.47 & 15.04 & 16.78 & 17.89 & 8.04 & 0.00 \\
\hline Stellar, \% & 0.51 & 1.99 & 3.48 & 4.96 & 6.45 & 7.19 & 5.39 & 0.00 & 0.00 & 0.00 \\
\hline
\end{tabular}

Source: authors' own study.

The portfolios, formed on the basis of this model, are more diversified than the previous ones, which makes them more resistant to exchange rate volatilities.

To compare the portfolio performance, we introduce the following assumptions: the value of the basic portfolio formed on 12/15/2019 is 100 thousand US dollars; we evaluate the portfolio performance based on the value of the cryptocurrency as of $01 / 15 / 2020$. In addition, we compare their performance with the basic portfolio, which would consist of all the cryptocurrencies presented in the research, in equal proportion as of December 15, 2019, and the value of such a portfolio on $01 / 15 / 2020$. This was done in order to consider the overall market growth and to avoid hasty conclusions regarding the effectiveness of portfolios structure optimization methods.

Fig. 3 shows a comparison of the portfolios' value. Provided a uniform investment of funds in cryptocurrencies with the highest capitalization in the market, such a portfolio will increase by $45.2 \%$ over the month compared to the base volume of investments.

Portfolios formed using the Markowitz model also provide an increase in investment funds. However, only a group of portfolios with an expected daily return of more than $0.15 \%$ allows one to obtain an increase in the value of portfolios higher than an increase in the base portfolio. A similar situation is observed with portfolios formed on the basis of the Quasi-Sharpe model. The increase in the value of the portfolio exceeds the increase in the base portfolio, allows you to get a group of portfolios, the expected daily return of which exceeds $1.1 \%$.

Let us to consider individual cases of portfolio growth and their reasons. Figure 4 shows the dynamics of the value of a cryptocurrency with a monthly time difference in a portfolio formed on the basis of the Markowitz model, with an expected daily return of $0.21 \%$ and $4 \%$ total risk. In this version of the portfolio, investments are made into three cryptocurrencies. Among them, Bitcoin SV and Binance Coin have a relatively high expected return rate and provide portfolio growth, but they are high-risk. On the other hand, Tether cryptocurrency is low-yield, but it provides a reduction in the overall risk of the portfolio in case of other cryptocurrencies adverse fluctuations. The feasibility of investing in this portfolio is doubtful because of the low level of its diversification. 
Evaluating crypto portfolio performance

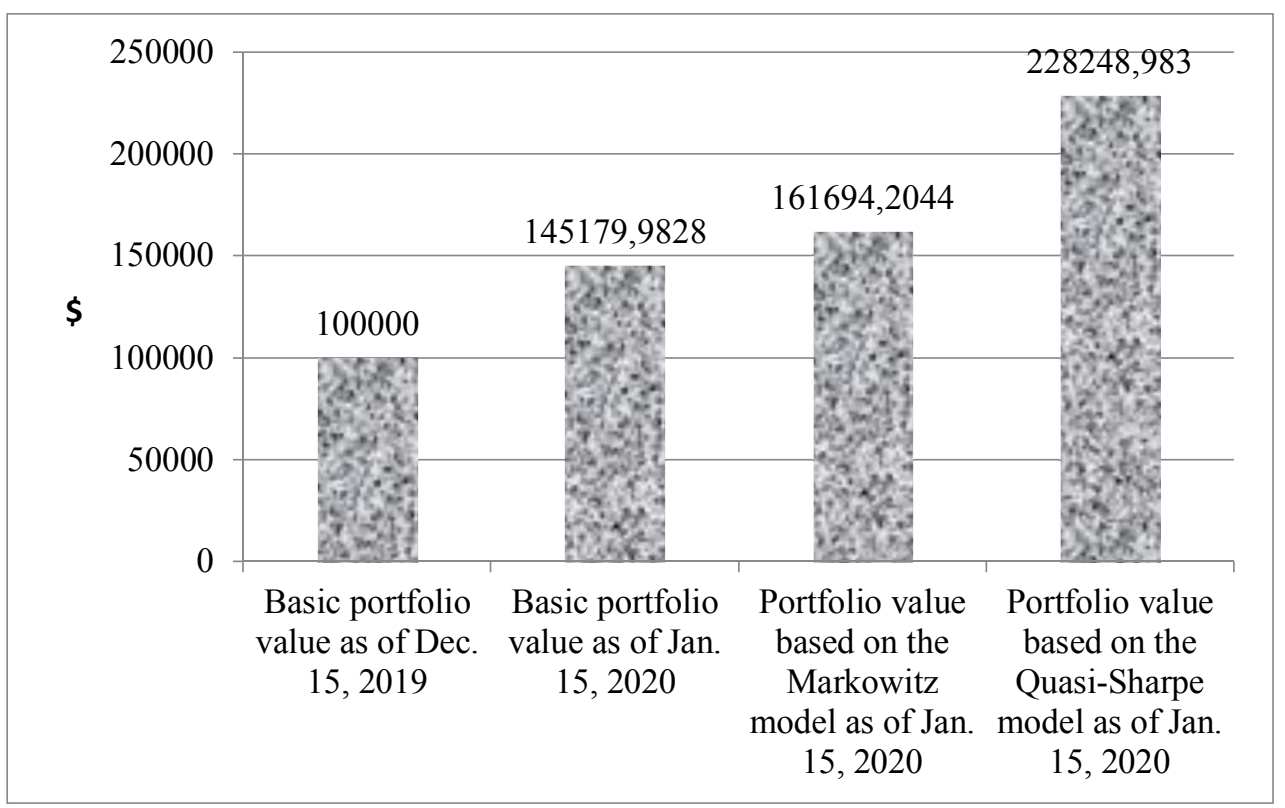

Fig. 3. Portfolio comparisons

Source: authors' own study.

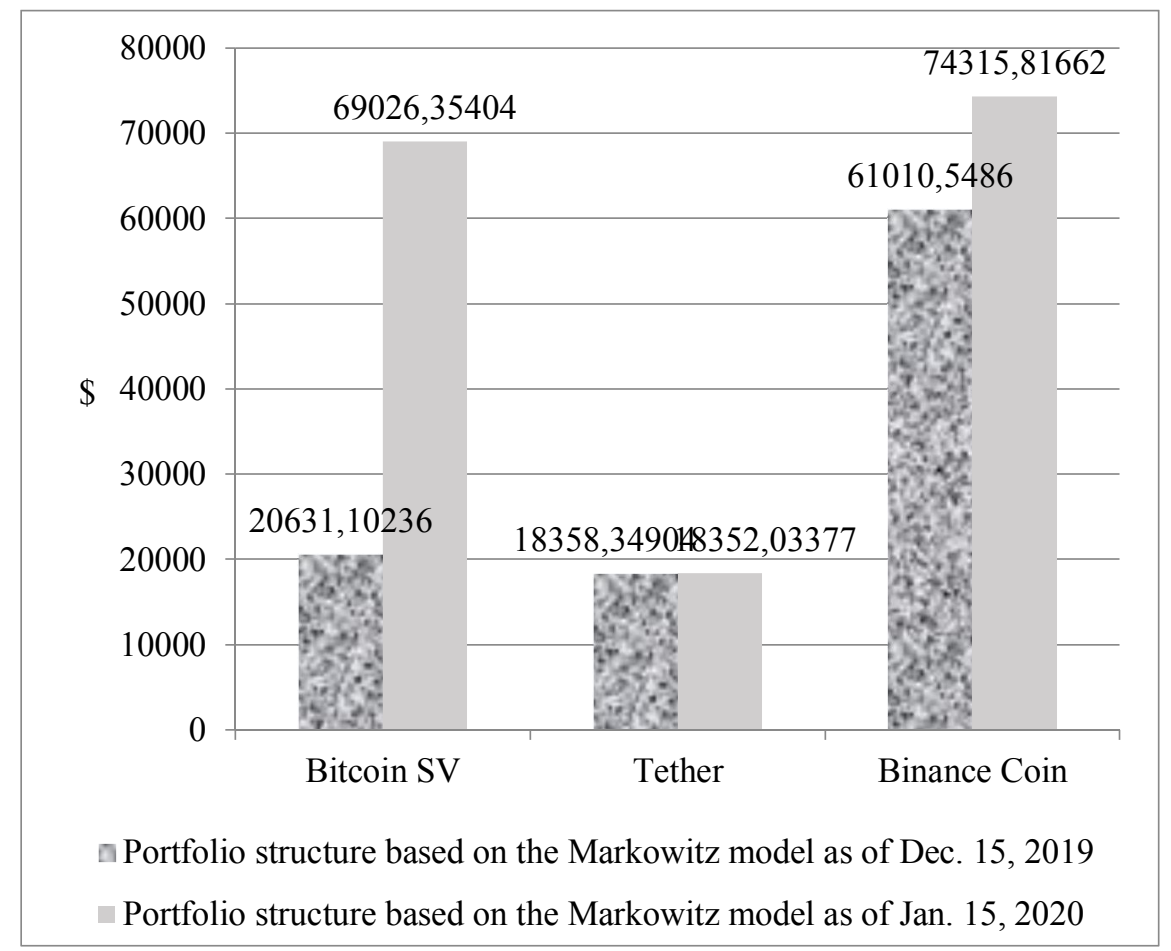

Fig. 4. Dynamics of portfolio based on the Markowitz model

Source: authors' own study.

And although some portfolios formed on the basis of the Markowitz model show a high increase in the investments value, however, investing in a more diversified base portfolio is less risky in this case.

Figure 5 represents the dynamics of the cryptocurrency value with a monthly time difference in the portfolio, formed on the basis of the Quasi-Sharpe model, with an expected daily return of $1.51 \%$ and an overall risk of $3 \%$. Note that the main increase in the portfolio was due to the growth in the value of 


\section{Yu. Kondrat, N. B. Yaroshevych, M. V. Lyvdar, R. I. Drala}

Bitcoin SV, however, there was an increase in all the instruments included in the portfolio. This portfolio is more diversified compared to the previous one. So, portfolios formed on the basis of the Quasi-Sharpe model should be considered appropriate for investment.

The generally accepted and often used in finance indicator of market risk for both a single financial instrument and an investment portfolio is the $\beta$-coefficient. It is calculated relative to the average market portfolio, which most often is the index portfolio and includes a financial instrument. Due to the fact that cryptocurrencies are not included in common indices, the calculation of $\beta$ is impossible. Therefore, as an indicator reflecting the relationship between cryptocurrency and financial markets, we use the correlation coefficient.

Table 4 represents the results of calculating the correlation coefficient between cryptocurrency rate of return and common stock indices for the last year. The results of the calculations presented in Table 4 indicate a direct and reverse weak statistical relationship between the selected indicators.

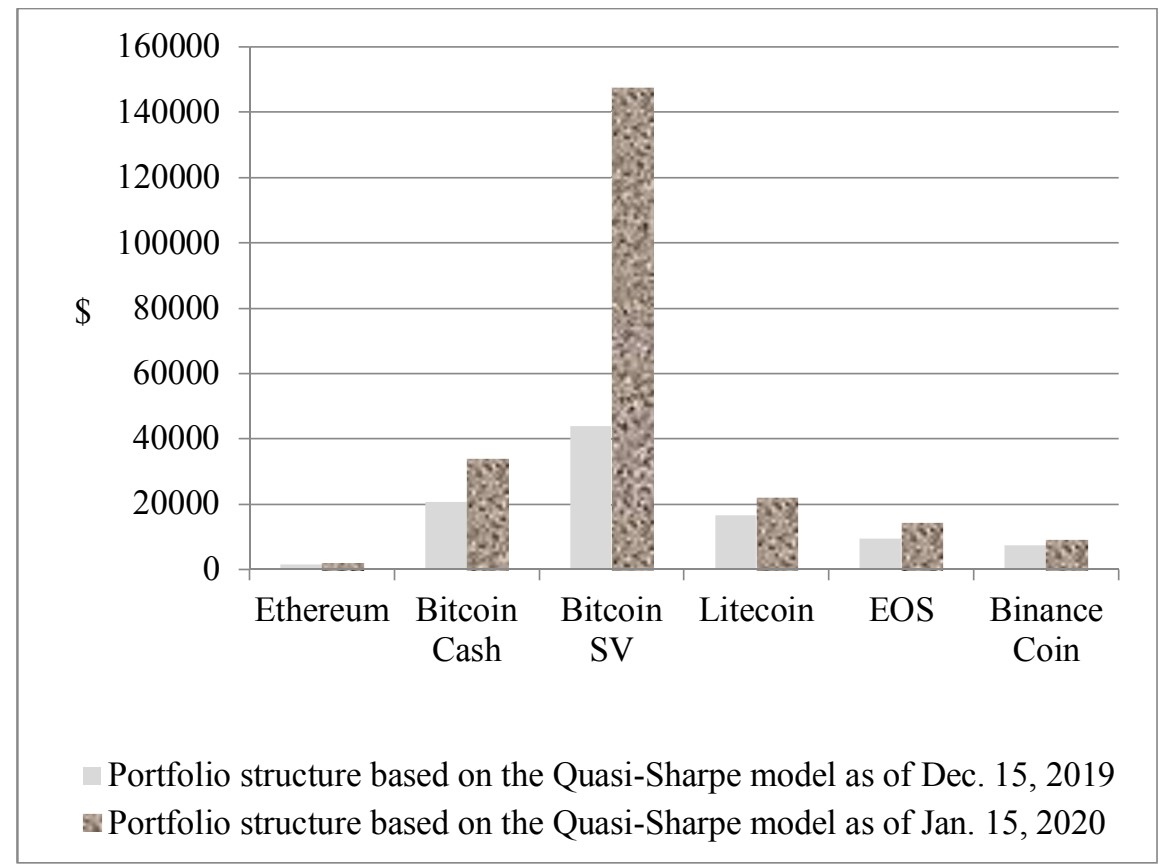

Fig. 5. Dynamics of portfolio based on the Quasi-Sharpe model

Source: authors' own study.

Table 4

Correlation matrix for cryptocurrencies and stock market indices

\begin{tabular}{|l|l|l|l|l|l|}
\hline Name & Euro Stoxx 50 & FTSE 100 & NASDAQ & Nikkei 225 & S\&P 500 \\
\hline Bitcoin & 0.0779 & -0.0004 & 0.0532 & -0.0280 & 0.0324 \\
\hline Ethereum & 0.1267 & 0.0882 & 0.0226 & -0.0062 & 0.0261 \\
\hline XRP & 0.1072 & 0.1290 & 0.0358 & 0.0035 & 0.0406 \\
\hline Tether & 0.0412 & 0.0719 & 0.0375 & -0.0105 & 0.0318 \\
\hline Bitcoin Cash & 0.0802 & 0.0592 & -0.0948 & -0.1372 & -0.1073 \\
\hline Litecoin & 0.1183 & 0.0791 & 0.0367 & 0.0118 & 0.0245 \\
\hline EOS & 0.1158 & 0.0265 & -0.0177 & -0.0187 & -0.0188 \\
\hline Binance Coin & 0.1441 & 0.1377 & 0.0045 & -0.0199 & 0.0064 \\
\hline Bitcoin SV & 0.0217 & 0.0171 & -0.0104 & -0.0582 & 0.0070 \\
\hline Stellar & 0.1352 & 0.0918 & 0.0487 & -0.0360 & 0.0606 \\
\hline
\end{tabular}

Source: authors' own study.

It must therefore be concluded that correlation between cryptocurrencies and traditional financial assets is virtually non-existent. That is, they could be applied to diversify the investment portfolio. 


\section{Evaluating crypto portfolio performance}

\section{Conclusions}

At the moment, cryptocurrencies are used mainly as a speculative investment tool, which is characterized by significant price volatility, high risk. In order to justify the feasibility of investing in cryptocurrency for non-institutional investors, optimal portfolios have been formed using the Markowitz and Quasi-Sharpe models. Calculations showed that cryptocurrency portfolios, formed on the basis of the Markowitz model, allow you to get an increase in investment funds, but are not diversified enough. As a result of applying the Quasi-Sharpe model, a large number of diversified portfolios with different rates of return have been obtained, which have the highest efficiency in investing. It has been empirically established that cryptocurrencies have a weak correlation with traditional financial asset classes, so it is advisable to include them in the securities portfolio in order to diversify it.

Despite significant returns, investing in cryptocurrencies is associated with risk due to excessive volatility, lack of government or central bank support, limited transaction processing speed, uncertain legal status, liquidity problems, and cybercriminal activities.

\section{Prospects for further research}

The unresolved status of cryptocurrencies in Ukraine hinders the crypto operations development, including portfolio investment in cryptocurrency. The direction of further research would be largely determined by the progress in cryptocurrency market regulation (their destination at financial market, taxation, etc.).

1. Glaser, F., Zimmermann, K., Haferkorn, M., Weber, M. C., \& Siering, M. (2014). Bitcoin-asset or currency? revealing users' hidden intentions. Revealing Users' Hidden Intentions (April 15, 2014). ECIS. https://pdfs.semanticscholar.org/3c7d/998b88bf48c88cf693625d2852706e7cb8e4.pdf.

2. Giudici, G., Milne, A. \& Vinogradov, D. Cryptocurrencies: market analysis and perspectives. J. Ind. Bus. Econ. 47, 1-18 (2020). https://doi.org/10.1007/s40812-019-00138-6.

3. Baur, D.G., Hong, K. and Lee, A.D. (2018) Bitcoin: Medium of Exchange or Speculative Assets? Journal of International Financial Markets, Institutions and Money, 54, 177-189. https://doi.org/10.1016/j.intfin.2017.12.004.

4. Slav'yuk R., Shkvarchuk L., Kondrat I. (2017). Financial market imbalance: reasons and peculiarities of occurrence in Ukraine. Investment Management and Financial Innovations, 14 (1-1), 227-235. https://doi:10.21511/imfi.14(1-1).2017.09.

5. Bouri, E., Molnar, P., Azzi, G., Roubaud, D. and Hagfors, L.I. (2017). On the Hedge and Safe Haven Properties of Bitcoin: Is It Really More than a Diversifier? Finance Research Letters, 20, 192-198. https://doi.org/10.1016/j.frl.2016.09.025.

6. Poyser, O. (2018). Herding behaviour in cryptocurrency markets. arXiv preprint arXiv:1806.11348.

7. Gurdgiev, C., O'Loughlin, D., Chlebowski, B., 2019. "Behavioral Basis Of Cryptocurrencies Markets : Examining Effects Of Public Sentiment, Fear, And Uncertainty On Price Formation”, Journal of Financial Transformation, Capco Institute, vol. 49, pages 110-121.

8. Shiller, R. (2003). From Efficient Markets Theory to Behavioral Finance. Journal of Economic Perspectives, Vol. 17, No. 1. https://doi.org/10.2469/dig.v33.n4.1368.

9. Moosa Imad A., 2020. "The bitcoin: a sparkling bubble or price discovery?", Economia e Politica Industriale: Journal of Industrial and Business Economics, Springer;Associazione Amici di Economia e Politica Industriale, vol. 47(1), pages 93-113, March. DOI: 10.1007/s40812-019-00135-9.

10. https://cointelegraph.com/news/80-of-all-bitcoins-already-mined-only-42-million-coins-left-until-supplycap.

11. https://www.bloomberg.com/news/articles/2020-01-14/bitcoin-rises-to-november-high-on-renewed-cryptoenthusiasm?

12. Lagard K. (2018). Regulirovanie finansovykh tekhnologii [Financial technology regulation]. - Finance and development. No. 6. P. 9-10. (in Russian).

13. Adriano A., (2018). Kratkaia istoriia kriptoeiforii [A brief history of crypto euphoria]. - Finance and development. No. 6. P. 20-21. (in Russian).

14. Proekt Zakonu pro obigh Kryptovaljuty v Ukrajini [Draft law about circulation of cryptocurrencies in Ukraine]. Available at: http://w1.c1.rada.gov.ua/pls/ zweb2/webproc4_1?pf3511=62684 (in Ukrainian). 


\section{Yu. Kondrat, N. B. Yaroshevych, M. V. Lyvdar, R. I. Drala}

15. Zakon Ukrainy vid 06.12.2019 No. 361-IX "Pro zapobihannia ta protydiiu lehalizatsii (vidmyvanniu) dokhodiv, oderzhanykh zlochynnym shliakhom, finansuvanniu teroryzmu ta finansuvanniu rozpovsiudzhennia zbroi masovoho znyshchennia" [Law of Ukraine dated 06/12/2019 No 361-IX On the prevention and counteraction to the legalization (laundering) of proceeds of crime, the financing of terrorism and the financing of the proliferation of weapons of mass destruction]. Available at: https://zakon.rada.gov.ua/laws/show/361-20 (in Ukrainian).

16. Proekt zakonu "Pro vnesennia zmin do Podatkovoho kodeksu Ukrainy ta inshykh zakoniv Ukrainy shchodo opodatkuvannia operatsii z kryptoaktyvamy" [Draft law on amendments to the Tax Code of Ukraine and other laws of Ukraine on taxation of operations with crypto-assets]. Available at: http://w1.c1.rada.gov.ua/pls/zweb2/webproc4_1?pf3511=67423 (in Ukrainian).

17. Kondrat I., Drala R. (2019). Portfelnyi menedzhment kryptovaliut [Portfolio management with cryptocurrencies]. Market infrastructure. No. 33. P. 293-299. Available at: http://www.marketinfr.od.ua/journals/2019/33_2019_ukr/33_2019.pdf(in Ukrainian).

1. Glaser, F., Zimmermann, K., Haferkorn, M., Weber, M. C., \& Siering, M. (2014). Bitcoin-asset or currency? revealing users' hidden intentions. Revealing Users' Hidden Intentions (April 15, 2014). ECIS. https://pdfs.semanticscholar.org/3c7d/998b88bf48c88cf693625d2852706e7cb8e4.pdf.

2. Giudici, G., Milne, A. \& Vinogradov, D. Cryptocurrencies: market analysis and perspectives. J. Ind. Bus. Econ. 47, 1-18 (2020). https://doi.org/10.1007/s40812-019-00138-6.

3. Baur, D. G., Hong, K. and Lee, A. D. (2018). Bitcoin: Medium of Exchange or Speculative Assets? Journal of International Financial Markets, Institutions and Money, 54, 177-189. https://doi.org/10.1016/j.intfin.2017.12.004.

4. Slav’yuk R., Shkvarchuk L., Kondrat I. (2017). Financial market imbalance: reasons and peculiarities of occurrence in Ukraine. Investment Management and Financial Innovations, 14 (1-1), 227-235. https://doi:10.21511/imfi.14(1-1).2017.09.

5. Bouri, E., Molnar, P., Azzi, G., Roubaud, D. and Hagfors, L. I. (2017). On the Hedge and Safe Haven Properties of Bitcoin: Is It Really More than a Diversifier? Finance Research Letters, 20, 192-198. https://doi.org/10.1016/j.frl.2016.09.025.

6. Poyser, O. (2018). Herding behaviour in cryptocurrency markets. arXiv preprint arXiv:1806.11348.

7. Gurdgiev, C., O'Loughlin, D., Chlebowski, B., 2019. "Behavioral Basis Of Cryptocurrencies Markets : Examining Effects Of Public Sentiment, Fear, And Uncertainty On Price Formation”, Journal of Financial Transformation, Capco Institute, vol. 49, pages 110-121.

8. Shiller, R. (2003). From Efficient Markets Theory to Behavioral Finance. Journal of Economic Perspectives, Vol. 17, No. 1. https://doi.org/10.2469/dig.v33.n4.1368.

9. Moosa Imad A., 2020. “The bitcoin: a sparkling bubble or price discovery?", Economia e Politica Industriale: Journal of Industrial and Business Economics, Springer;Associazione Amici di Economia e Politica Industriale, vol. 47(1), pages 93-113, March. DOI: 10.1007/s40812-019-00135-9.

10. https://cointelegraph.com/news/80-of-all-bitcoins-already-mined-only-42-million-coins-left-until-supplycap.

11. https://www.bloomberg.com/news/articles/2020-01-14/bitcoin-rises-to-november-high-on-renewed-cryptoenthusiasm?

11. Лагард К. Регулирование финансовых технологий // Финансы и развитие. 2018. Июнь. С. 9-10.

13. Адриано А. Краткая история криптоэйфории // Финансы и развитие. 2018. Июнь. - С. 20-21.

14. Проект закону України від 06.10.2017 № 7183 “Про обіг криптовалюти в Україні”. URL: http://w1.c1.rada.gov.ua/pls/zweb2/webproc4_1?pf3511=62684.

15. Закон України від 06.12.2019 № 361-IX “Про запобігання та протидію легалізації (відмиванню) доходів, одержаних злочинним шляхом, фінансуванню тероризму та фінансуванню розповсюдження зброї масового знищення”. URL: https://zakon.rada.gov.ua/laws/show/361-20.

16. Проект закону “Про внесення змін до Податкового кодексу України та інших законів України щодо оподаткування операцій з криптоактивами”. URL: http://w1.c1.rada.gov.ua/pls/zweb2/webproc4_1?pf3511=67423.

17. Кондрат I., Драла Р. (2019). Портфельний менеджмент криптовалют. Інфраструктура ринку. Вип. 33. С. 293-299. http://www.market-infr.od.ua/journals/2019/33_2019_ukr/33_2019.pdf. 


\title{
Evaluating crypto portfolio performance
}

І. Ю. Кондрат, Н. Б. Ярошевич, М. В. Ливдар, Р. І. Драла Національний університет “Львівська політехніка”, кафедра фінансів

\section{ОЦІНЮВАННЯ ЕФЕКТИВНОСТІ ПОРТФЕЛЯ 3 КРИПТОВАЛЮТ}

\author{
() Кондрат I. Ю., Ярошевич Н. Б., Ливдар М. В., Драла Р. І., 2020
}

Криптовалюта привертас багато уваги академічної спільноти, портфельних інвесторів, державних регуляторів та широкої громадськості. Ще не до кінця зрозуміло, чи це тип цифрового фінансового активу, чи нова форма грошей. Правовий статус криптовалюти суттсво відрізнясться в різних країнах і с невизначеним в Україні.

Метою статті є визначення характерних ознак криптовалюти та їі правового статусу в Україні, формування оптимальних портфелів 3 криптовалют із різними дохідністю та ризиком, оцінка їх ефективності, вивчення можливостей диверсифікації портфеля за допомогою криптовалют у новій фінансовій реальності.

Ринок криптовалют мас три ключових відмінності від ринку традиційних фінансових активів: високий ризик у зв'язку з мінливістю дохідності, неясність фундаментальної цінності криптовалюти, інвестори неінституційні.

Визначено ключові характеристики криптовалюти: виключно цифрова форма; децентралізація; відсутність підтримки державних органів влади; анонімність; незворотність трансакцій; незначний інфляційний ризик; глобальність і швидкість трансакцій; відсутність посередника.

Незважаючи на поінформованість державних регуляторних органів про можливості й загрози, яких можна очікувати від функціонування криптовалюти, її правовий статус дуже істотно відрізняється у різних країнах: абсолютна заборона (Непал, Пакистан, В'єтнам та ін.); нейтральний статус (більшість країн світу), необхідність реєстрації та ліцензування операцій 3 криптовалютою (Італія, Австралія та Японія та ін.), дозвіл використовувати криптовалюту як законний платіжний засіб (острів Мен, Мексика).

Центральні банки наполегливо підкреслюють відмінність криптовалют, які не підтримуються жодним офіційним органом, від законних платіжних засобів та фінансових активів, усвідомлюючи небезпеку, яка загрожус інвесторам у криптовалюту через її спекулятивний характер. Ураховуючи, що криптовалюти потенційно можуть використовуватися для фінансування незаконних операцій, ухилення від сплати податків тощо, то розроблення і впровадження нормативних актів, які регулюють ії функціонування, зараз на часі. У законопроекті запропоновано розглядати криптоактив як вид віртуального активу у формі токену, який створюсться, обліковується та відчужується в розподіленому ресстрі та не посвідчує майнових та/або немайнових прав власника криптоактиву. Тому криптовалюту можна розглядати як актив, придатний для портфельного інвестування.

Для обгрунтування доцільності інвестицій у криптовалюти неінституціональними інвесторами були побудовані оптимальні портфелі, використовуючи моделі Марковіца та Квазі-Шарпа. Розрахунки показали, що портфелі криптовалют, виконані на основі моделі Марковіца, дозволяють підвищити інвестиційну прибутковість, але недостатньо диверсифіковані. Велику кількість диверсифікованих портфелів із різними дохідністю та ризиком було отримано за допомогою моделі Квазі-Шарпа. Для оцінювання ефективності одержаних портфелів 3 криптовалют їх порівняно в динаміці, а також з базовим портфелем, який складається 3 десяти криптовалют із найвищою капіталізацісю на ринку в рівних частках. Встановлено, що криптовалютам притаманний слабкий кореляційний зв'язок із традиційними фінансовими інструментами, тому їх доцільно включати до портфеля цінних паперів з метою його диверсифікації.

Ключові слова: криптовалюта, інвестиційний портфель, оптимізаційні моделі, ефективність портфеля, диверсифікація. 